\title{
Effect of the cryopreservation method used, the embryonic stage and the use of conjugated linoleic acid isomers on the cryotolerance of in vitro-produced bovine embryos
}

\author{
Efeito do método de criopreservação utilizado, estágio de \\ desenvolvimento embrionário e uso de isômeros do ácido linoleico \\ conjugado na criotolerância de embriões bovinos produzidos in vitro
}

\author{
Luciana Simões Rafagnin Marinho ${ }^{1 *}$; Lain Uriel Ohlweiler²; \\ Marcos Henrique Barreta ${ }^{3}$; Paulo Bayard Dias Gonçalves ${ }^{4}$; \\ Joana Claudia Mezzalira ${ }^{2}$; Alceu Mezzalira ${ }^{3}$
}

\begin{abstract}
Conjugated linoleic acid (CLA) might be able to improve the cryotolerance of in vitro-produced (IVP) embryos. The effect of two CLA isomers on the cryotolerance of bovine IVP embryos, as well as that of the stage of embryonic development and the method used for cryopreservation was evaluated by three experiments. In Experiment 1, oocytes $(n=3,917)$ were fertilized in vitro and cultured with $0,50,100$, or $200 \mu \mathrm{M}$ trans-10, cis-12 (t10, c12 CLA). In Experiment 2, fertilized oocytes ( $=2,131)$ were cultured with $100 \mu \mathrm{M} \mathrm{t10,c12} \mathrm{or} \mathrm{cis-9,} \mathrm{trans-11} \mathrm{(c9,} \mathrm{t11} \mathrm{CLA),} \mathrm{or} \mathrm{a} \mathrm{combination} \mathrm{of} \mathrm{both} \mathrm{isomers.} \mathrm{The} \mathrm{embryos}$ were vitrified at the blastocyst (BL) or the expanded blastocyst (EB) stage. In Experiment 3, oocytes ( $\mathrm{n}=$ 1,720 ) were fertilized and cultured with or without $100 \mu \mathrm{M} \mathrm{t10,c12} \mathrm{CLA}$, and the blastocysts were vitrified or frozen. Blastocyst development rate as well as the rates of re-expansion and hatching after thawing was recorded. Moreover, the mean cell number and mRNA expression of acetyl-CoA carboxylase (ACC1) and stearoyl-CoA desaturase (SCD1) as well as fatty acid synthase (FASN) multienzyme complex were determined. In Experiment 1, the highest concentration of t10, c12 CLA that did not reduce blastocyst development rate was $100 \mu \mathrm{M}$. In Experiment 2, the rates of re-expansion and hatching among the EBs obtained through IVP after supplementation with t10, c12 CLA (73.1\% and 57.7\%), with c9, t11 CLA $(80.0 \%$ and $68.6 \%)$, with the combination $(78.3 \%$ and $52.2 \%)$, and with the control group $(85.4 \%$ and $58.3 \%$ ) were similar. At the BL stage, the rates of re-expansion and hatching were lower than those at the EB stage, and CLA combination allowed a hatching rate (8.0\%) lower than that observed in the control group (40.0\%). In Experiment 3, the hatching rates for vitrified EBs (vitrified control; 67.4\%) and vitrified CLA EBs (65.8\%) were higher than those obtained for frozen EBs, exposed (13.3\%) or not exposed (28.6\%) to CLA. In addition, in Experiment 3, the hatching rate was higher at the EB stage in vitrified groups, while the rates of BL and EB were similar in frozen groups, thus proving that vitrification was more efficient than freezing for IVP bovine embryos. In Experiment 3, CLA isomer t10, C12 did not influence the embryonic cell number or mRNA expression of ACC1 and SCD1 enzymes, but decreased the mRNA expression of FASN. In conclusion, $100 \mu \mathrm{M}$ CLA did not affect subsequent embryonic development. However, neither CLA isomer improved the cryotolerance of IVP bovine embryos.
\end{abstract}

Key words: Freezing, lipid, mRNA expression, vitrification

\footnotetext{
${ }^{1}$ Discente, Universidade Estadual de Londrina, UEL, Londrina, PR, Brasil. E-mail: lucianaraf@gmail.com

${ }^{2}$ Discentes, Universidade do Estado de Santa Catarina, UDESC, Lages, SC, Brasil. E-mail: lainuriel@yahoo.com.br; joanamezzalira@yahoo.com.br

3 Profs., UFSC, Curitibanos, SC, Brasil. E-mail: barretamh@yahoo.com.br; alceu.mezzalira@udesc.br

${ }^{4}$ Prof., UFSM, Santa Maria, RS, Brasil. E-mail: bayard@ufsm.br

* Author for correspondence
} 


\section{Resumo}

Existem evidências de que o ácido linoleico conjugado (CLA) pode aumentar a criotolerância de embriões produzidos in vitro (PIV). O efeito de dois isômeros do CLA na criotolerância de embriões bovinos PIV, assim como o estágio de desenvolvimento e o efeito do método de criopreservação, foi avaliado através de três experimentos. No Experimento 1 , oócitos $(\mathrm{n}=3.917)$ foram fecundados in vitro e embriões foram cultivados com $0,50,100$ ou $200 \mu \mathrm{M}$ de trans-10, cis-12 (t10, c12 CLA). No Experimento 2, oócitos fecundados $(n=2.131)$ foram cultivados com $100 \mu \mathrm{M}$ de $\mathrm{t} 10$, c12 ou cis-9, trans-11 (c9, t11 CLA), ou ainda com uma associação de ambos. Os embriões foram vitrificados nos estágios de blastocisto (BL) ou blastocisto expandido (BE). No Experimento 3, oócitos $(n=1.720)$ foram fecundados e cultivados com ou sem $100 \mu \mathrm{M}$ de t10, c12 CLA e os blastocistos foram vitrificados ou congelados. As taxas de desenvolvimento dos blastocistos, bem como de re-expansão e eclosão após o reaquecimento foram observadas. Adicionalmente, o número médio de células e a expressão de mRNA das enzimas acetil-CoA carboxilase (ACC1) e estearoil-CoA dessaturase (SCD1) e do complexo enzimático ácido graxo sintase (FASN) foram avaliados. No Experimento 1, a maior concentração de t10, c12 CLA que não reduziu a taxa de blastocisto foi $100 \mu \mathrm{M}$. No Experimento 2, as taxas de re-expansão e eclosão obtidas entre EB obtidos por PIV após suplementação com t10, c12 CLA (73,1 e 57,7\%), com c9, t11 CLA (80,0 e 68,6\%), com a associação de ambos (78,3 e 52,2\%) e com o grupo Controle (85,4 e $58,3 \%$ ) foram similares. As taxas de re-expansão e eclosão foram mais baixas no estágio de BL do que no estágio de $\mathrm{BE}$, e a associação dos isômeros apresentou taxa de eclosão $(8,0 \%)$ mais baixa do que a do grupo controle (40,0\%). No Experimento 3, as taxas de eclosão obtidas com os grupos BE vitrificado (controle vitrificado; 67,4\%) e BE CLA vitrificado $(65,8 \%)$ foram mais altas do que as obtidas com BE congelados, expostos (13.3\%) ou não (28.6\%) ao CLA. Também no Experimento 3, as taxas de eclosão foram mais altas com embriões em estágio de BE nos grupos vitrificados, enquanto nos grupos congelados as taxas de BL e BE foram similares, provando que a vitrificação foi mais eficiente do que o congelamento para embriões bovinos PIV. No Experimento 3, também foi observado que o CLA não influenciou o número de células dos embriões ou a expressão de mRNA das enzimas ACC1 e SCD1, mas reduziu a expressão de mRNA do complexo enzimático FASN. Em conclusão, $100 \mu \mathrm{M}$ CLA não afetou o desenvolvimento embrionário subsequente. Entretanto, os isômeros do CLA não melhoraram a criotolerância de embriões bovinos PIV.

Palavras-chave: Congelação, lipídeo, expressão de mRNA, vitrificação

\section{Introduction}

In vitro-produced (IVP) embryos are more sensitive to cryopreservation than their in vivoderived counterparts (LEIBO; LOSKUTOFF, 1993; PRYOR et al., 2011). IVP embryos differ from the in vivo-produced embryos in many aspects, including lower buoyant density (POLLARD; LEIBO, 1994), incomplete compaction (WOLFE; BRYANT, 1999), darker cytoplasm (DIEZ et al., 2001), and increased lipid levels (CROSIER et al., 2000; FAIR et al., 2001). Despite all these factors, there is evidence that the low survival rate of cryopreserved IVP embryos is mainly due to the increased amount of lipid granules within the cytoplasm (ABE et al., 2002; MCEVOY et al., 2000).
Lipid droplets directly affect the survival of chilled embryos by undergoing irreversible changes and compromising further developmental competence (WOLFE; BRYANT, 1999). Oocytes and embryos have a wide profile of fatty acids, with different chain lengths and degrees of saturation. Consequently, transition phases can occur at different temperatures, and several phases can coexist, resulting in severe cell damage (WOLFE; BRYANT, 1999).

Recently, the use of high-mass resolution desorption electrospray ionization-mass spectrometry (DESI-MS) has shown differences in the homeostasis of cholesterol and fatty acid metabolism between IVP blastocysts and their in vivo-generated counterparts (GONZÁLEZ- 
SERRANO et al., 2013). The same methodology showed a distinct lipid profile in oocytes from indicus and $1 / 2$ indicus $\mathrm{x}$ taurus bovine females (SILVA-SANTOS et al., 2014). Moreover, distinct mass spectrometry profiles were obtained for phosphatidylcholine and sphingomyelin species, including the differences due to breed (Simmental vs. Nelore) and culture conditions (in vitro or in vivo) (SUDANO et al., 2012). Importantly, cryopreservation is known to impact the membrane lipid profile of IVP bovine embryos (LEÃO et al., 2014).

Reducing lipid content can be considered as an approach to produce embryos that more closely resemble the in vivo-generated ones. This is possible by embryo culture in serum-free systems (ORDOÑEZ-LEON et al., 2014) or by mechanical removal of intracellular lipids (KAWAKAMI et al., 2008). However, both approaches reduce the developmental viability of embryos. Another way to reduce the lipid content of embryos would be to reduce the extent of lipidogenesis.

Conjugated linoleic acid (CLA) has two main isomers: the trans-10, cis-12 (t10, c12 CLA) and the cis-9, trans-11 (c9, t11 CLA). t10, c12 CLA is able to decrease the lipid content in human and animal cells, mainly by reducing the uptake and synthesis of fatty acids (PARIZA et al., 2001). The mechanisms that can reduce lipid synthesis involve down-regulation of mRNA expression of key lipogenic enzymes associated with fat synthesis (TSUBOYAMA-KASAOKA et al., 2000; BAUMGARD et al., 2002).

The addition of 110, c12 CLA to the culture medium decreased the lipid content and increased the cryotolerance of IVP bovine embryos (PEREIRA et al., 2007, 2008). In addition to the effect on lipid metabolism, the antioxidant action exerted by CLA, particularly by t10, c12 isomer (FAGALI; CATALÁ, 2008), may improve embryo cryotolerance. Conversely, Darwich et al. (2010) found no improvement in the survival of cryopreserved embryos after the addition of t10, c12 CLA.

In addition, different actions were exerted by the distinct CLA isomers. The c9, t11 CLA induced partial recovery of the cells from the growth inhibition induced by palmitate, while t10, c12 CLA induced full recovery of these cells (DONNELLY et al., 2009). Therefore, it is possible that differences exist with the cryotolerance of IVP embryos.

We aimed to determine the optimal concentration of t10, c12 CLA or c9, t11 CLA or their combination in the culture medium by assessing their influence on cryotolerance (freezing and vitrification) of bovine IVP embryos at the blastocyst (BL) and expanded blastocyst (EB) stage, the rates of cleavage and BL formation, number of cells, and mRNA expression of the lipogenesis-related enzymes acetyl-CoA carboxylase (ACC1) and stearoyl-CoA desaturase (SCD1) and fatty acid synthase (FASN) multienzyme complex.

\section{Materials and Methods}

Except where otherwise indicated, all chemicals were obtained from Sigma Chemical Co. (St. Louis, MO, USA).

\section{Experimental design}

Experiment 1 (11 replicates) evaluated the effect of adding $0,50,100$ or $200 \mu \mathrm{M} \mathrm{t10,} \mathrm{c12}$ CLA (Matreya, ref. 001254) to the culture medium of fertilized oocytes $(\mathrm{n}=3,917)$ on embryo development. In Experiment 2 (five replicates), fertilized oocytes $(n=2,131)$ were cultured in the medium without CLA (control group), with 100 $\mu \mathrm{M}$ (concentration indicated by Experiment 1) t10, c12 CLA, with $100 \mu \mathrm{M}$ c9, t11 CLA (Matreya, ref. 001255), or their combination containing $50 \mu \mathrm{M}$ of each isomer. The embryos obtained from each treatment were separately vitrified according to their developmental stage, BL or EB. In Experiment 
3 (six replicates), fertilized oocytes $(n=1,720)$ were cultured without CLA (control group) or with 100 $\mu \mathrm{M}$ t10, c12 CLA (the isomer used in Experiment 2 ), and the BLs were subjected to freezing or vitrification. Cell number and mRNA expression of the enzymes ACC1 and SCD1 and FASN were also assessed in Experiment 3.

\section{Oocyte recovery and maturation}

Ovaries were collected at a local slaughterhouse and transported in saline solution at $25-35{ }^{\circ} \mathrm{C}$ to the laboratory within $\sim 3 \mathrm{~h}$. Follicles ranging from 2 to $8 \mathrm{~mm}$ in diameter were aspirated through an 18-gauge needle connected to a vacuum pump by using an aspiration flow of $15 \mathrm{~mL}$ water/min. Only oocytes enclosed in a compact cumulus with evenly granulated cytoplasm were selected for in vitro maturation (IVM). Selected cumulus oocyte complexes (COCs) were placed in groups of 40 in four-well plates (NUNC, Roskilde, Denmark). Each well contained $400 \mu \mathrm{L}$ of IVM medium (TCM-199 with Earle's salt, and $25 \mathrm{mM}$ Hepes), supplemented with $26.2 \mathrm{mM}$ sodium bicarbonate, $0.2 \mathrm{mM}$ sodium pyruvate, $0.01 \mathrm{UI} / \mathrm{mL}$ FSH (Folltropin; Bioniche, Animal Health, Canada), $0.5 \mu \mathrm{g} / \mathrm{mL}$ LH (Lutropin; Bioniche, Animal Health, Canada), and 10\% estrus mare serum (EMS). The COCs were incubated for $22-24 \mathrm{~h}$ at $39{ }^{\circ} \mathrm{C}$ in a humidified atmosphere containing $5 \% \mathrm{CO}_{2}$ in air.

\section{In vitro fertilization (IVF)}

Frozen-thawed semen was selected by $45 \%$ and 90\% Percoll gradient (Nutricell, Campinas, São Paulo, Brazil), and used at a concentration of $1 \times 10^{6}$ spermatozoa $/ \mathrm{mL}$. The fertilization medium (FertTALP) was supplemented with $30 \mu \mathrm{g} / \mathrm{mL}$ heparin, $30 \mu \mathrm{g} / \mathrm{mL}$ penicillamine, $15 \mu \mathrm{M}$ hypotaurine, and 1 $\mu \mathrm{M}$ epinephrine. Semen and COCs were incubated for $18-22 \mathrm{~h}$ at $39{ }^{\circ} \mathrm{C}$ in a humidified atmosphere with $5 \% \mathrm{CO}_{2}$ in air. The day of fertilization was considered as day 0 (D0).

\section{In vitro culture (IVC)}

Presumptive zygotes were denuded by successive pipetting and transferred to wells containing $400 \mu \mathrm{L}$ of SOFaaci supplemented with $5 \%$ EMS. Embryo culture was performed at $39^{\circ} \mathrm{C}$ in a humidified atmosphere with $5 \% \mathrm{CO}_{2}, 5 \% \mathrm{O}_{2}$, and $90 \% \mathrm{~N}_{2}$. Dishes containing the culture medium were previously incubated for $24 \mathrm{~h}$ for the total dilution of CLA.

\section{Embryo vitrification and warming}

Embryos were vitrified in glass micropipettes, according to their developmental stage, either BL or EB. First, they were exposed for $1 \mathrm{~min}$ to $10 \%$ ethylene glycol $(\mathrm{EG})+10 \%$ propanediol $(\mathrm{PROH})$ solution, and immediately transferred to $20 \%$ EG $+20 \%$ PROH vitrification solution, where the embryos were maintained for 20-25 s. During the last step, 3-4 embryos were quickly loaded into the micropipettes and directly plunged into liquid nitrogen. For warming, the micropipettes were held in air for $4 \mathrm{~s}$, and then the narrow end was immersed in TCM-199 solution containing 10\% EMS and 0.3 $\mathrm{M}$ sucrose heated to $35^{\circ} \mathrm{C}$. After $5 \mathrm{~min}$, the embryos were transferred to $0.15 \mathrm{M}$ sucrose solution for additional $5 \mathrm{~min}$. The embryos were then cultured in SOFaaci supplemented with $5 \%$ EMS at $39{ }^{\circ} \mathrm{C}$ for 3 days, in a humidified atmosphere of $5 \% \mathrm{CO}_{2}, 5 \%$ $\mathrm{O}_{2}$, and $90 \% \mathrm{~N}_{2}$.

\section{Embryo freezing and thawing}

The embryos at the BL and EB stages were separately transferred to a cryoprotectant solution containing 1.5 M EG and loaded into 0.25-mL plastic straws (IMV Technologies, France). The straws were placed in a programmable embryo freezer (Dominium K Biocom, Uberaba MG, Brazil), previously stabilized at $-7{ }^{\circ} \mathrm{C}$, and then these straws were seeded. Ten minutes later, the freezing curve experiment was carried out at a 
rate of $0.5{ }^{\circ} \mathrm{C} / \mathrm{min}$ until $-35^{\circ} \mathrm{C}$, when the embryos were plunged into liquid nitrogen. For thawing, the straws were held in air for $4 \mathrm{~s}$ and placed in a $35{ }^{\circ} \mathrm{C}$ water bath for another $30 \mathrm{~s}$. The embryos were cultured in SOFaaci containing 5\% EMS for additional 3 days.

\section{Embryo evaluation criteria}

The cleavage rate was assessed at D2, and the blastocyst formation rate, at D7. The rates of re-expansion and hatching were evaluated in Experiments 2 and 3. In Experiment 3, 13-20 embryos exposed to each treatment were collected for estimating the total cell number $(\mathrm{TCN})$. The embryos were fixed in absolute ethanol containing $10 \mu \mathrm{g} / \mathrm{mL}$ bisbenzimide (Hoechst 33342) for $7 \mathrm{~min}$. Then, the embryos were placed on a slide in a $10-\mu \mathrm{L}$ glycerol droplet and covered with a coverslip, and the nuclei were counted under ultraviolet light in an epifluorescent inverted microscope.

\section{$R N A$ extraction and real-time PCR}

Embryos cultured in $100 \mu \mathrm{M}$ t10, c12 CLA or without CLA (control) were used for mRNA expression analysis. Ninety fresh hatched blastocysts obtained at D7 or D8 from Experiment 3 were used in each group. Embryos were submitted to three baths in phosphate-buffered saline containing $0.3 \%$ bovine serum albumin (BSA; fatty acid-free) and stored in plastic tubes in an ultra-freezer at $-80^{\circ} \mathrm{C}$ until RNA extraction. Total RNA was extracted using Trizol, according to the manufacturer's instructions, and was quantified by determining the absorbance at $260 \mathrm{~nm}$ using a NanoDrop 1000 spectrophotometer (Thermo Scientific, Waltham, Massachusetts, USA). RNA integrity was electrophoretically verified on $1 \%$ agarose gel stained by ethidium bromide and the purity was obtained by the rate of absorption (OD260/OD280). Values $<1.8$ were not used in this study. Total RNA (600 ng) was first treated with $0.2 \mathrm{U}$ of DNase (Invitrogen, Carlsbad, USA) at $37^{\circ} \mathrm{C}$ for $5 \mathrm{~min}$ to digest contaminants, and then heated to $65^{\circ} \mathrm{C}$ for $3 \mathrm{~min}$. The RNA was reversely transcribed (RT) in the presence of $1 \mu \mathrm{M}$ oligo (dT) primer, 4 U Omniscript RTase (Omniscript RT Kit; Qiagen, Mississauga, ON, Canada), $0.5 \mu \mathrm{M}$ dideoxynucleotide triphosphate (dNTP) mix, and $10 \mathrm{U}$ RNase Inhibitor (Invitrogen) in a volume of $20 \mu \mathrm{L}$ at $37^{\circ} \mathrm{C}$ for $1 \mathrm{~h}$. The reaction was terminated by incubation at $93{ }^{\circ} \mathrm{C}$ for $5 \mathrm{~min}$.

Real-time polymerase chain reaction (PCR) was performed to amplify genes encoding ACC1, SCD1, and FASN. Real-time PCR was undertaken in a Step One Plus instrument (Applied Biosystems, Foster City, CA) with Platinum SYBR Green qPCR SuperMix (Invitrogen) and bovine-specific primers. Common thermal cycling parameters (3 min at $95^{\circ} \mathrm{C}, 40$ cycles of $15 \mathrm{~s}$ at $95^{\circ} \mathrm{C}, 30 \mathrm{~s}$ at 60 ${ }^{\circ} \mathrm{C}$, and $30 \mathrm{~s}$ at $72^{\circ} \mathrm{C}$ ) were used to amplify each transcript. Melting curve analyses were performed to verify the identity of the product. The samples were run in duplicate and were expressed relative to histone $\mathrm{H} 2 \mathrm{~A}$ as the housekeeping gene. The relative quantification of gene expression for each treatment was calculated according to the description provided by Pfaffl (2001). Bovine-specific primers (Table 1) were designed using Primer Express Software v 3.0 (Applied Biosystems) and synthesized by Invitrogen. 
Table 1. Primer sequences and concentrations used for expression analysis of candidate genes.

\begin{tabular}{lllcc}
\hline \multicolumn{1}{c}{ Gene } & & \multicolumn{1}{c}{ Sequence } & $\begin{array}{c}\text { Primer concentration } \\
(\mu \mathrm{M})\end{array}$ & $\begin{array}{c}\text { Reference or } \\
\text { Accession no. }\end{array}$ \\
\hline Histone H2A & $\mathrm{F}$ & GAGGAGCTGAACAAGCTGTTG & 200 & $(4)$ \\
& $\mathrm{R}$ & TTGTGGTGGCTCTCAGTCTTC & 200 & \\
\multirow{2}{*}{ ACC1 } & $\mathrm{F}$ & GAGTTCCTCCTTCCCATCTACC & 200 & NM174224.2 \\
& $\mathrm{R}$ & AAGGTGCGTGAAGTCTTCCAA & 200 & \\
SCD1 & $\mathrm{F}$ & TGGGAAGGGCCTTGATGAT & 200 & NM173959.4 \\
& $\mathrm{R}$ & ACACCATGCATGCTGACTCTCT & 200 & \\
FASN & $\mathrm{F}$ & CGGTCGATTCCTGGAAATTG & 200 & NM001012669.1 \\
& $\mathrm{R}$ & CAGTAGGATCCCGTGGAAAGTC & 200 & \\
\hline
\end{tabular}

\section{Statistical analysis}

The rates of cleavage and blastocyst formation were compared using $\chi^{2}$ test (Minitab ${ }^{\circledR}$; State College, EUA) at a significance level of $5 \%$. The data regarding cell number were analyzed by ANOVA and the differences between mean values were tested using Student's test $\left(\right.$ Minitab ${ }^{\circledR}$; State College, EUA), also at a significance level of 5\%. The data about mRNA expression were compared by analysis of variance using PROC GLM procedure of statistical SAS package. Different treatments were used as the "main effect," and different replicates, as the "random variable". All continuous variables were tested for normality by the Shapiro-Wilk test and normalized whenever necessary.

\section{Results}

Experiment 1 - different doses of t10, c12 CLA

Group $50 \mu \mathrm{M}$ CLA showed the highest cleavage rate $(79.0 \%)$, which did not differ from that of the control group $(76.5 \%)$, but was significantly higher than that of the groups $100 \mu \mathrm{M}$ CLA $(73.9 \%)$ and
$200 \mu \mathrm{M}$ CLA $(74.9 \%)$. No difference was noted among the rate of blastocyst formation in the control (26.0\%), $50 \mu \mathrm{M}$ CLA (26.6\%), and $100 \mu \mathrm{M}$ CLA (26.4\%) groups. The lowest BL formation rate $(P<0.05)$ was observed for $200 \mu \mathrm{M}$ CLA group (20.2\%).

Experiment 2 - different CLA isomers and their combination

The cleavage rate was similar in all groups $(P>$ 0.05 ), ranging from $79.7 \%$ to $81.9 \%$. BL formation rate was also similar, ranging from $19.9 \%(\mathrm{c} 9, \mathrm{t} 11$ group) to $23.1 \%$ (combination group).

Embryos at the EB stage showed no difference in the rate of re-expansion across treatments $(P>$ 0.05; Table 2). Similarly, no significant difference was observed in the hatching rate when the embryos were vitrified at the EB stage. Conversely, at the BL stage, the rates of re-expansion and hatching of vitrified embryos were lower than that observed at the EB stage (Table 2). The combination group showed significantly lower rates of re-expansion $(28.0 \%)$ and hatching $(8.0 \%)$ than the control group (55\% and $40 \%$, respectively). 
Table 2. Viability of IVP bovine embryos cultured with $100 \mu \mathrm{M}$ CLA isomers (two types), individually or in combination $(50 \% \mathrm{v} / \mathrm{v})$, and vitrified and warmed at the expanded blastocyst (EB) or blastocyst (BL) stage.

\begin{tabular}{|c|c|c|c|c|c|}
\hline \multirow[t]{2}{*}{ Treatment } & \multicolumn{2}{|c|}{ Vitrified embryos } & \multirow{2}{*}{$\begin{array}{c}\text { Re-expansion rate } \\
\%\end{array}$} & \multicolumn{2}{|c|}{ Hatching rate } \\
\hline & Stage & $\mathrm{N}$ & & $\mathrm{n}$ & $\%$ \\
\hline Control & EB & 48 & 85.4 & 28 & 58.3 \\
\hline $\mathrm{t} 10, \mathrm{c} 12 \mathrm{CLA}$ & EB & 26 & 73.1 & 15 & 57.7 \\
\hline c9, t11 CLA & EB & 35 & 80.0 & 24 & 68.6 \\
\hline CLA combination & EB & 46 & 78.3 & 24 & 52.2 \\
\hline Control & $\mathrm{BL}$ & 20 & $55.0^{\mathrm{ab}}$ & 8 & $40.0^{\mathrm{a}}$ \\
\hline $\mathrm{t} 10, \mathrm{c} 12 \mathrm{CLA}$ & $\mathrm{BL}$ & 26 & $65.4^{\mathrm{a}}$ & 4 & $15.4^{\mathrm{ab}}$ \\
\hline c9, t11 CLA & $\mathrm{BL}$ & 19 & $42.1^{\mathrm{ab}}$ & 4 & $21.1^{\mathrm{ab}}$ \\
\hline CLA combination & $\mathrm{BL}$ & 25 & $28.0^{\mathrm{b}}$ & 2 & $8.0^{\mathrm{b}}$ \\
\hline
\end{tabular}

The mean values at the EB stage do not differ $\left(\chi^{2}\right.$ test; $\left.\mathrm{P}>0.05\right)$.

The mean values indicated with a different superscript within the BL columns differ $\left(\chi^{2}\right.$ test; $\left.P<0.05\right)$.

Experiment 3 - freezing and vitrification of BLs or EBs cultured in medium with or without CLA

At the BL stage, regardless of CLA addition, vitrification provided a higher re-expansion rate than freezing (Table 3). However, at this stage, the hatching rate was not influenced by the cryopreservation method or by CLA addition. In embryos cryopreserved at the EB stage, the rate of re-expansion was higher in the vitrified groups, irrespective of CLA addition. The same pattern was observed for hatching rate: the vitrified groups showed a higher hatching rate than the frozen groups, irrespective of CLA addition.

Table 3. Viability of IVP bovine embryos cultured with or without $100 \mu \mathrm{M}$ t10, c12 CLA, and vitrified or frozen at the blastocyst (BL) or expanded blastocyst (EB) stage

\begin{tabular}{ccccccc}
\hline Treatment & \multicolumn{2}{c}{ Embryos } & \multicolumn{2}{c}{ Re-expansion rate } & \multicolumn{2}{c}{ Hatching rate } \\
\cline { 2 - 7 } & Stage & $\mathrm{n}$ & $\mathrm{n}$ & $\%$ & $\mathrm{n}$ & $\%$ \\
\hline Vitrification & $\mathrm{BL}$ & 20 & 11 & $55.0^{\mathrm{A}}$ & 5 & $25.0^{\mathrm{A}}$ \\
Freezing & $\mathrm{BL}$ & 25 & 5 & $20.0^{\mathrm{B}}$ & 5 & $20.0^{\mathrm{A}}$ \\
CLA + Vitrification & $\mathrm{BL}$ & 22 & 16 & $72.7^{\mathrm{A}}$ & 6 & $27.3^{\mathrm{A}}$ \\
CLA + Freezing & $\mathrm{BL}$ & 29 & 7 & $24.1^{\mathrm{B}}$ & 3 & $10.3^{\mathrm{A}}$ \\
\hline Vitrification & EB & 46 & 40 & $87.0^{\mathrm{a}}$ & 31 & $67.4^{\mathrm{a}}$ \\
Freezing & $\mathrm{EB}$ & 42 & 19 & $45.2^{\mathrm{b}}$ & 12 & $28.6^{\mathrm{b}}$ \\
CLA + Vitrification & EB & 38 & 33 & $86.8^{\mathrm{a}}$ & 25 & $65.8^{\mathrm{a}}$ \\
CLA + Freezing & EB & 30 & 11 & $36.7^{\mathrm{b}}$ & 4 & $13.3^{\mathrm{b}}$ \\
\hline
\end{tabular}

The mean values indicated with a different superscript ${ }^{\mathrm{AB}}$ within the BL columns or ${ }^{\mathrm{ab}}$ within the EB columns differ $\left(\chi^{2}\right.$ test; $P<$ $0.05)$.

Embryos at the BL and EB stages subjected to similar treatments were also compared. In the embryos not exposed to CLA, the re-expansion rate of vitrified and frozen EBs was higher than that of vitrified and frozen BLs $(P<0.05)$. However, in the groups exposed to CLA, no difference was observed in the re-expansion rate between vitrified $\mathrm{BL}$ and EB embryos (72.7\% vs. $86.6 \%)$ and frozen BL and 
EB embryos (24.1\% vs. $36.7 \%)$.

Embryos at the EB stage showed a higher hatching rate than those at the $\mathrm{BL}$ stage in the vitrified control $(67.4 \%$ vs. $25.0 \%)$ and CLA $(65.8 \%$ vs. $27.3 \%)$ groups. In the frozen groups, a very low hatching rate was observed, similar for the BL control (20.0\%), BL CLA (10.3\%), EB control (28.6\%), and EB CLA (13.3\%) groups.

In frozen/thawed embryos, ruptured zona pellucida, empty zona, and broken embryos were frequent; however, in vitrified/re-warmed embryos, these phenomena were rarely observed. Irrespective of treatment, the re-expansion rate was higher after vitrification than after freezing.

\section{Estimation of TCN}

The mean cell number of BLs treated with t10, c12 CLA was $87.4 \pm 27$, similar to that observed for the control group $(88.8 \pm 21.9)$. t10, c12 CLA did not alter cell number, even in embryos at different stages of development.

\section{$A C C 1, S C D 1$, and FASN mRNA expression}

Although t10, c12 CLA did not affect the mRNA expression of ACC1 and SCD1 when compared to the control group $(P>0.05)$, it reduced the mRNA expression of FASN (Figure 1).

Figure 1. Relative mRNA expression (mean \pm standard error of mean) of the enzymes ACC1, SCD1, and FASN in bovine in vitro-produced embryos cultured with and without trans-10, cis-12 CLA (CLA and control, respectively).

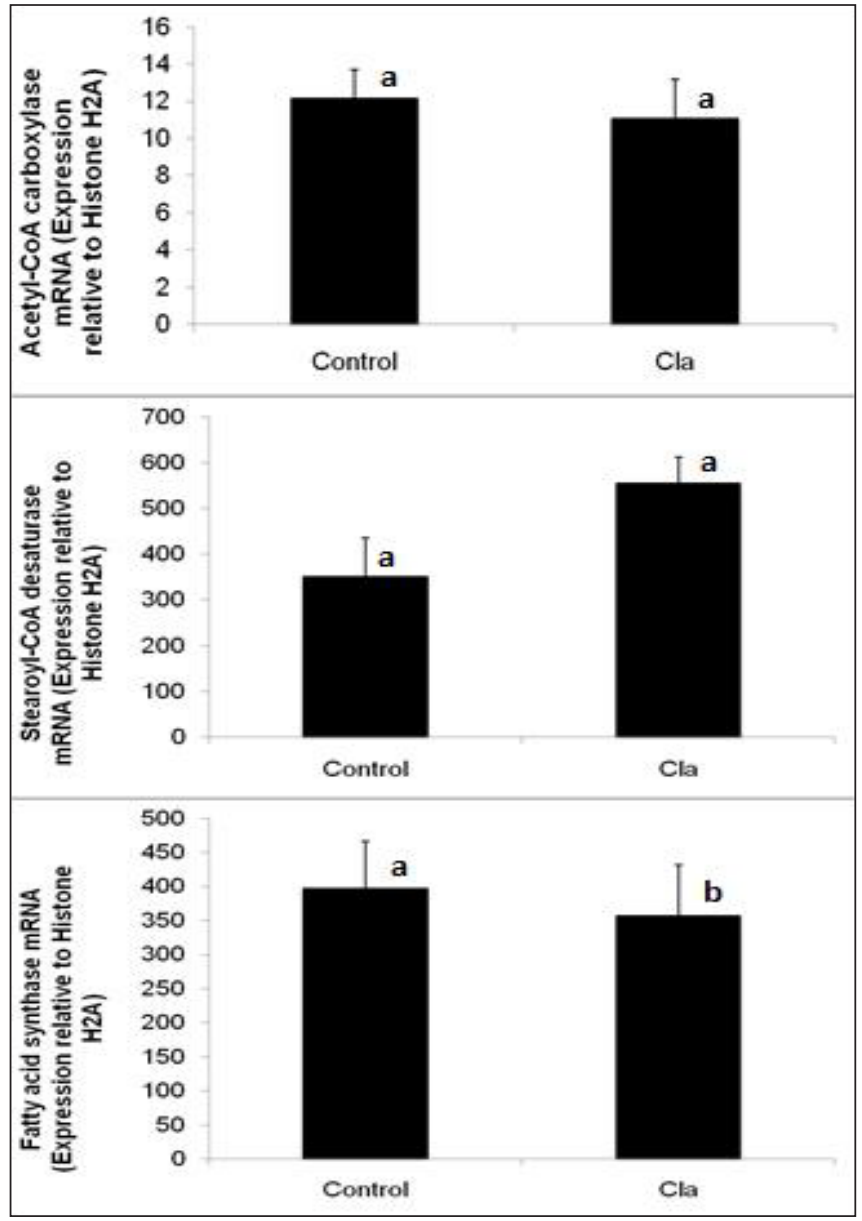

Different superscripts indicate significant difference $(P<0.05)$. 


\section{Discussion}

The significant findings of this study were as follows: 1 ) addition of up to $100 \mu \mathrm{Mt} 10$, c12 CLAdid not negatively influence blastocyts formation rate or the average cell population, but the addition of 200 $\mu \mathrm{M}$ t10, c12 CLA impaired embryo development; 2) addition of $100 \mu \mathrm{M} \mathrm{t10,} \mathrm{c12} \mathrm{or} \mathrm{c9,} \mathrm{t11} \mathrm{CLA}$ or their combination (50 $\mu \mathrm{M}$ of each) did not improve the cryotolerance of IVP bovine embryos; 3) addition of $100 \mu \mathrm{M} t 10, \mathrm{c} 12$ CLA reduced the mRNA expression of FASN, but it did not alter the mRNA expression of ACC1 and SCD1; 4) embryo viability after vitrification was influenced by the developmental stage; 5) vitrification and freezing provided similar results in embryos at the BL stage; and 6) vitrification is more suitable than freezing for cryopreservation of bovine IVP EB embryos.

Adequate survival rate after in vitro embryo cryopreservation, especially in the bovine species, has been one of the main research objectives in the last few decades. Many studies have tried to evaluate the effect of approaches such as increasing the cooling and re-warming speed with super-cooled nitrogen (WERLICH et al., 2006), use of cytoskeletal stabilizers (PRYOR et al., 2011), and use of different cryoprotectant combinations and reduced volumes of cryopreservation solution (TANIGUCHI et al., 2007; RIOS et al., 2010). Unfortunately, so far, none of the proposed strategies consistently improved the viability of bovine cryopreserved IVP embryos to the levels observed for in vivo-generated embryos.

Recently, evidence has indicated that instead of searching for a suitable cryopreservation protocol, it would be more appropriate to adapt in vitro embryo production systems, attempting to reduce the differences between in vitro and in vivo-produced embryos. Intracellular lipid content appears to be an important cause of cellular alteration during cryopreservation, reducing the survival rate after rewarming of embryos. One way to produce embryos with higher similarity to their in vivo-generated counterparts would be through reduction of lipid content. CLA has been shown to reduce the lipid content of various tissues; however, distinct CLA isomers present divergent effects. Exposure to a commercial CLA mixture reduced cell growth in breast cancer and treatment with $8 \mu \mathrm{M}$ palmitic acid aided recovery from growth inhibition (DONNELLY et al., 2009). Absalón-Medina et al. (2014) reported an increase in lipid content and a decrease in the mRNA expression of the $70-\mathrm{kDa}$ heat shock protein 1A (HSPA1A) when the IVP bovine embryos were exposed to t10, c12 CLA; conversely, a higher blastomere count was observed in embryos treated with c9,t11 before vitrification. Our study evaluated the effect of addition of both isomers, alone and in combination, on the cryotolerance of bovine IVP embryos. Because of the scarcity of information regarding the use of CLA in embryos, the maximum concentration that does not decrease embryo viability had to be confirmed. We observed that concentrations up to $100 \mu \mathrm{M}$ t10, c12 CLA did not affect blastocyst formation rate. This finding agrees with previous observations (PEREIRA et al., 2007, 2008).

A different pathway was reported by Darwich et al. (2010), who observed a decrease in D7 BL formation rate with the addition of $100 \mu \mathrm{M} \mathrm{t10,c12}$ CLA to the culture medium (16.0\%) compared to that observed in the control group (26.4\%). This difference, however, disappeared by D8. We also showed that treatment with $200 \mu \mathrm{M} \mathrm{t10,} \mathrm{c12} \mathrm{CLA}$ decreased $\mathrm{BL}$ formation rate, compared to the control group. The results obtained in Experiment 1 allowed us to consider $100 \mu \mathrm{M}$ t10, c12 CLA as the standard concentration for further experiments, and this concentration was extrapolated to the isomer c9, t11 CLA.

In Experiment 2, embryos were cultured with $100 \mu \mathrm{M} \mathrm{t10,}$, 12 CLA or $100 \mu \mathrm{M}$ c9, t11 CLA or a combination of both CLAs. As in Experiment 1 , no negative effects of the isomers, alone or in combination, were observed. Similar mean cell numbers observed for the embryos of the control group $(88.8 \pm 21.9)$ and the t10, c12 CLA group (87.4 
\pm 27 ) also indicated the absence of any negative influence of this isomer at $100 \mu \mathrm{M}$. Donnelly et al. (2009) did not observe any effects of a commercial mixture of CLA or the pure isomers ( $99, \mathrm{t} 11$ and t10, c12 CLA) on the growth of the nonlipogenic epithelial HeLa cells.

No increase in cryotolerance was observed in the vitrified embryos exposed to either of the two CLA isomers. In addition, an unexpected decrease in hatching rate (8\%) was observed with the combination treatment in vitrified BLs. Data regarding the effect of CLA isomers on embryo cryotolerance are controversial. Darwich et al. (2010) also observed no increase in the cryotolerance of IVP bovine embryos, vitrified at D7 and D8 after culture with t10, c12 CLA. Absalón-Medina et al. (2014) reported that c9,t11 CLA, but not t10, c12 CLA, improved the quality of bovine IVP embryos after cryopreservation, and that the lipid content of embryos was increased by $110, \mathrm{c} 12$ CLA. On the other hand, Batista et al. (2014) observed a decrease in the neutral lipid content and an increase in the re-expansion rate of embryos cultured with t10, c12 CLA, compared to the control $(56.3 \%$ vs. $34.4 \%)$; however, the hatching rate was similar among the groups. Pereira et al. (2007) observed a decrease in lipid content (evaluated by Nomarski microscopy) in the embryos cultured with t10, c12 CLA or in serumfree SOF and an increase in their cryotolerance. In the same study, although the embryos cultured in serum-free SOF showed a greater reduction in lipid content than the CLA-treated group, they were less cryotolerant than the CLA-treated embryos; this phenomenon was attributed to the increased membrane fluidity determined by CLA. However, the CLA-treated groups also received $100 \mu \mathrm{M}$ glutathione, which was not included in serumfree SOF, and might have influenced the results. Moreover, the authors refer to only the rate of reexpansion as the viability criterion for assessing cryopreservation, when the most suitable criteria for assessing further embryonic development would be hatching rate or post-transfer pregnancy. Given the findings of previous studies on the potential benefits of CLA supplementation of the embryo culture medium, a more systematic investigation was warranted.

Recent findings obtained using highmass resolution DESI-MS indicate that IVP BLs significantly differ from their in vivogenerated counterparts in terms of homeostasis of cholesterol and fatty acid metabolism (GONZÁLEZ-SERRANO et al., 2013). Using similar methodology, Silva-Santos et al. (2014) showed a distinct lipid profile of the oocytes from indicus and $1 / 2$ indicus $\mathrm{x}$ taurus. This confirms that different breeds and embryo production systems are associated with distinct lipid profiles and the metabolism of preimplantation embryos. Moreover, mass spectrometry profiles of phosphatidylcholine and sphingomyelin species differ according to the unsaturation level and carbon chain composition in bovine blastocysts, because of both subspecies and culture conditions (SUDANO et al., 2012). This may explain the controversial results obtained in different CLA studies. Our study did not evaluate the lipid content of embryos; however, the mRNA expression of ACC1, FASN, and SCD (enzymes related to lipogenesis) was assessed. Reduced expression of lipogenesis-related genes and consequent depletion of long-chain fatty acids is a major mechanism underlying CLAinduced inhibition of growth of breast cancer cells (DONNELLY et al., 2009). The enzyme ACC1 and the enzymatic complex FASN are involved in determining the composition of the fatty acid chain, and their mRNA expression is strongly decreased by 110, c 12 CLA in the adipose and mammary gland tissues (CORL et al., 2008; KADEGOWDA et al., 2010). Darwich et al. (2010) observed that t10, c12 CLA increased SCD expression in bovine IVP embryos, compared to the control group cultured in mSOF plus 5\% FCS. In this study, no decrease was observed in ACC1 and SCD mRNA expression in the IVP embryos cultured with 100 
$\mu \mathrm{M}$ t10, c12 CLA. Nevertheless, a decrease was detected in FASN mRNA expression, which was statistically significant, but not as pronounced as the decrease observed in mammary gland tissues (BAUMGARD et al., 2002; KADEGOWDA et al., 2010). Batista et al. (2014) have not observed any change in the FASN mRNA expression in bovine embryos cultured with $100 \mu \mathrm{M}$ t10, c12 CLA. Although, in the present study, CLA significantly reduced FASN mRNA expression, this effect might not have been enough to exert a major influence on the genetic control of fatty acid synthesis in IVP bovine embryos. This may suggest a distinct CLA response pathway in embryonic cells.

Although no direct effects of CLA have been observed in this study, the behavioral differences between embryos cryopreserved at different stages of development are noteworthy. In a previous study, in which the embryos were not exposed to CLA, our group observed a distinct behavior after vitrification of the embryos at the same stage, but cryopreservation at D7 or D8 (MEZZALIRA et al., 2004). In this study, embryos at an early developmental stage (BLs) were less cryotolerant than those at a later developmental stage (EBs), similar to what was reported by Morató et al. (2010). During BL formation and expansion, lipids are metabolized by the trophoblastic cells, which may explain the increased cryotolerance of EBs compared to the BL-stage IVP bovine embryos.

Further, at the BL stage, the combination of $50 \mu \mathrm{M}$ t10, c12 and $50 \mu \mathrm{M}$ c9, t11 CLA caused a deleterious effect, with a strong reduction in the hatching rate, compared to the control group ( $8 \%$ vs. $40 \%$ ). EB stage embryos showed higher cryotolerance to vitrification than BL stage embryos. However, no effects of treatment were observed and similar rates of re-expansion and hatching were noted in both control and treated groups. Frozen EBs exposed or unexposed to CLA presented lower rates of reexpansion and hatching compared to vitrified EBs. At the BL stage, there was a significant reduction in the re-expansion rate in the freezing group versus the vitrified group (20.0\% vs. $55.0 \%)$ and the CLA freezing group versus the CLA vitrification group $(24.1 \%$ vs. $72.7 \%)$. On the other hand, freezing induced similar low hatching rate in BL embryos exposed to all forms of treatment (Table 3). In addition, the occurrence of ruptured embryos, with or without ruptured zona, reinforces that the freezing process is harmful to IVP bovine embryos.

Therefore, further studies are needed to determine whether CLA acts on lipid metabolism in embryonic cells as well as the possible underlying mechanisms. Studies regarding the effect of t10, c12 CLA on other enzymes related to lipid metabolism in embryos should be encouraged, especially the ones using tools that provide detailed information, such as high-mass resolution DESI-MS.

We can infer that the addition of concentrations

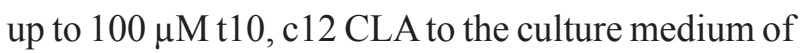
IVP embryos does not affect subsequent embryonic development or cell number, but it decreases FASN mRNA expression. It can also be concluded that, under the conditions of this experiment, the addition of $\mathrm{t} 10, \mathrm{c} 12$ CLA or $\mathrm{c} 9, \mathrm{t} 11$ CLA isomers, alone or in combination, is not indicated to improve the cryotolerance of bovine IVP embryos. Further, t10, c12 CLA does not alter the mRNA expression of ACC1 and SCD1 in embryos. In addition, we showed a distinct pattern of viability after vitrification of IVP bovine embryos, as determined by their developmental stage; this viability was not influenced by CLA addition during culture. Irrespective of CLA addition, vitrification and freezing offered identical viability in bovine IVP embryos at the BL stage; however, vitrification was more suitable than freezing for EBs. Furthermore, we showed that the EB stage is a more appropriate stage to cryopreserve bovine IVP embryos than the BL stage.

\section{Acknowledgements}

This study was funded by the Brazilian Council for Scientific and Technological Development 
(CNPq). We thank Dr. Paulo Bayard Gonçalves and Dr. João Francisco de Oliveira for their generous cooperation with these experiments. We also thank Verdi, Fox, and El'Golli abattoirs for providing the ovaries.

\section{References}

ABE, H.; YAMASHITA, S.; SATOH, T.; HOSHI, H. Accumulation of cytoplasmatic lipid droplets in bovine embryos and cryotolerance of embryos developed in different culture systems using serum-free medium or in serum-containing medium. Molecular Reproduction and Development, New York, v. 61, n. 1, p. 57-66, 2002.

ABSALÓN-MEDINA, V. A.; BEDFORD-GUAUS, S. J.; GILBERT, R. O.; SIQUEIRA, L. C.; ESPOSITO, G.; SCHNEIDER, A.; CHEONG, S. H.; BUTLER, W. $\mathrm{R}$. The effects of conjugated linoleic acid isomers cis9 , trans-11 and trans-10,cis-12 on in vitro bovine embryo production and cryopreservation. Journal of Dairy Science, Champaign, v. 97, n. 10, p. 6164-6176, 2014.

BATISTA, R. I.; RAPOSO, N. R.; CAMPOS-JUNIOR, P. H.; PEREIRA, M. M.; CAMARGO, L. S.; CARVALHO, B. C.; GAMA, M. A.; VIANA, J. H. Trans-10, cis-12 conjugated linoleic acid reduces neutral lipid content and may affect cryotolerance of in vitro-produced crossbred bovine embryos. Journal of Animal Science and Biotechnology, London, v. 5, n. 33, p. 1-8, 2014.

BAUMGARD, L. H.; MATITASHVILI, E.; CORL, B. A.; DWYER, D. A.; BAUMAN, D. E. Trans-10, cis-12 conjugated linoleic acid decreases lipogenic rates and expression of genes involved in milk lipid synthesis in dairy cows. Journal of Dairy Science, Champaign, v. 85, n. 9, p. 2155-2163, 2002.

CORL, B. A.; OLIVER, S. A. M.; LIN S.; OLIVER, W. T.; MA, Y.; HARRELL, R. J.; ODLE, J. Conjugated linoleic acid reduces body fat accretion and lipogenic gene expression in neonatal pigs fed low- or high-fat formulas. Journal of Nutrition, Bethesda, v. 138, n. 3, p. 449-454, 2008.

CROSIER, A. E.; FARIN, P. W.; DYKSTRA, M. J.; ALEXANDER, J. E.; FARIN, C. E. Ultrastructural morphometry of bovine compact morulae produced in vivo or in vitro. Biology of Reproduction, Madison, v. 62, n. 5, p. 1459-1465, 2000.

DARWICH, A. A.; PERREAU, C.; PETIT, M. H.; PAPILLIER, P.; DUPONT, J.; GUILLAUME, D.; MERMILLOD, P.; GUIGNOT, F. Effect of PUFA on embryo cryoresistance, gene expression and AMPK $\alpha$ phosphorylation in IVF-derived bovine embryos. Prostaglandins \& Other Lipid Mediators, New York, v. 93, n. 1-2, p. 30-36, 2010.

DIEZ, C.; HUYMAN, Y.; Le BOURHIS, D.; GUYADER-JOLY, C.; DEGROUARD, J.; RENARD, J. P. Delipidating in vitro-produced bovine zygotes: effect on further development and consequences for freezability. Theriogenology, Stoneham, v. 55, n. 4, p. 923-936, 2001.

DONNELLY, C.; OLSEN, A. M.; LEWIS, L. D.; EISENBERG, B. L.; EASTMAN, A.; KINLAW, W. B. Conjugated linoleic acid (CLA) inhibits expression of the Spot 14 (THRSP) and Fatty Acid Synthase genes and impairs the growth of human breast cancer and liposarcoma cells. Nutrition and Cancer, London, v. 61, n. 1, p. 114-122, 2009.

FAGALI, N.; CATALÁ, A. Antioxidant activity of conjugated linoleic acid isomers, linoleic acid and its methyl ester determined by photoemission and DPPH techniques. Biophysical Chemistry, New York, v. 137, n. 1, p. 56-62, 2008.

FAIR, T.; LONERGAN, P.; DINNYES, A.; COTTELL, D. C.; HYTTEL, P.; WARD, F. A.; BOLAND, M. P. Ultrastructure of bovine blastocysts following cryopreservation: effect of method of blastocyst production. Molecular Reproduction and Development, New York, v. 58, n. 2, p. 186-195, 2001.

GONZÁLEZ-SERRANO, A. F.; PIRRO, V.; FERREIRA, C. R.; OLIVERI, P.; EBERLIN, L. S.; HEINZMANN, J.; LUCAS-HAHN, A.; NIEMANN, H.; COOKS, R. G. Desorption electrospray ionization mass spectrometry reveals lipid metabolism of individual oocytes and embryos. PLOS ONE, Cambridge, v. 8, n. 9, e74981, 2013.

KADEGOWDA, A. K. G.; CONNOR, E. E.; TETER, B. B.; SAMPUGNA, J.; DELMONTE, P.; PIPEROVA, L. S.; ERDMAN, R. A. Dietary trans fatty acid isomers differ in their effects on mammary lipid metabolism as well as lipogenic gene expression in lactating mice. Journal of Nutrition, Bethesda, v. 140, n. 5, p. 919-924, 2010.

KAWAKAMI, M.; KATO, Y.; TSUNODA, Y. The effects of time of first cleavage, developmental stage, and delipidation of nuclear-transferred porcine blastocysts on survival following vitrification. Animal Reproduction Science, Champaign, v. 106, n. 3-4, p. 402-411, 2008.

LEÃO, B. C.; ROCHA-FRIGONI. N. A.; CABRAL, E. C.; FRANCO, M. F.; FERREIRA C. R.; EBERLIN, M. N.; FILGUEIRAS, P. R.; MINGOTI, G. Z. Membrane lipid profile monitored by mass spectrometry detected 
differences between fresh and vitrified in vitro-produced bovine embryos. Zygote, Naples, p. 1-10, 2014.

LEIBO, S. P.; LOSKUTOFF, N. M. Cryobiology of in vitro-derived bovine embryos. Theriogenology, Stoneham, v. 39, n. 1, p. 81-94, 1993.

MCEVOY, T. G.; COULL, G. D.; BROADBENT, P. J.; HUTCHINSON, J. S. M.; SPEAKE, B. K. Fatty acid composition of lipids in immature cattle, pig and sheep oocytes with intact zona pellucida. Journal of Reproduction and Fertility, London, v. 118, n. 1, p. 163170, 2000.

MEZZALIRA, A.; MEZZALIRA, J. C.; MORAES, A. N.; THALER NETO, A.; VIEIRA, A. D.; BARRETA, M. H.; DAMIANI, J. Vitrification of bovine IVP embryos: Age of embryos and exposure time to cryoprotectant influence viability. Archives of Veterinary Science, Curitiba, v. 9, n. 2, p. 107-111, 2004.

MORATÓ, R.; IZQUIERDO, D.; PARAMIO, M. T.; MOGAS, T. Survival and apoptosis rates after vitrification in cryotop devices of in vitro-produced calf and cow blastocysts at different developmental stages. Reproduction, Fertility and Development, Champaign, v. 22, n. 7, p. 1141-1147, 2010.

ORDOÑEZ-LEON, E. A.; MERCHANT, H.; MEDRANO, A.; KJELLAND, M.; ROMO, S. Lipid droplet analysis using in vitro bovine oocytes and embryos. Reproduction in Domestic Animals, Linköping, v. 49, n. 2, p. 306-314, 2014.

PARIZA, M. W.; PARK, Y.; COOK, M. E. The biologically active isomers of conjugated linoleic acid. Progress in Lipid Research, Kent, v. 40, n. 4, p. 283-298, 2001.

PEREIRA, R. M.; BAPTISTA, M. C.; VASQUES, M. I.; HORTA, A. E. M.; PORTUGAL, P. V.; BESSA, R. J. B.; CHAGAS E SILVA, J.; SILVA PEREIRA, M.; MARQUES, C. C. Cryo-survival of bovine blastocysts is enhanced by culture with trans-10 cis-12 conjugated linoleic acid (10t, 12c CLA). Animal Reproduction Science, Amsterdam, v. 98, n. 3-4, p. 293-301, 2007.

PEREIRA, R. M.; CARVALHAIS, I.; PIMENTA, J.; BAPTISTA, M. C.; VASQUES, M. I.; HORTA, A. E. M.; SANTOS, I. C.; MARQUES, M. R.; REIS, A.; SILVA PEREIRA, M.; MARQUES, C. C. Biopsied and vitrified bovine embryos viability is improved by trans 10 , cis 12 conjugated linoleic acid supplementation during in vitro embryo culture. Animal Reproduction Science, Amsterdam, v. 106, n. 3-4, p. 322-332, 2008.

PFAFFL, M. W. A new mathematical model for relative quantification in realtime RT-PCR. Nucleic Acids Research, Oxford, v. 29, n. 9, e45, 2001.
POLLARD, J. W.; LEIBO, S. P. Chilling sensitivity of mammalian embryos. Theriogenology, Stoneham, v. 41, n. 1, p. 101-106, 1994.

PRYOR, J. H.; LOONEY, C. R.; ROMO, S.; KRAEMER, D. C.; LONG, C. R. Cryopreservation of in vitro produced bovine embryos: effects of lipid segregation and postthaw laser assisted hatching. Theriogenology, Stoneham, v. 75, n. 1, p. 24-33, 2011.

RIOS, G. L.; MUCCI, N. C.; KAISER, G. G.; ALBERIO, R. H. Effect of container, vitrification volume and warming solution on cryosurvival of in vitro-produced bovine embryos. Animal Reproduction Science, Amsterdam, v. 118, n. 1, p. 19-24, 2010.

SILVA-SANTOS, K. C.; FERREIRA, C. R.; SANTOS, G. M. G.; EBERLIN, M. N.; SILOTO, L. S.; ROSA, C. O.; MARCANTONIO T. N.; SENEDA, M. M. MALDIMS lipid profiles of oocytes recovered by ovum pickup from bos indicus and 1/2 indicus 3 taurus with high vs low oocyte yields. Reproduction in Domestic Animals, Linköping, v. 49, n. 5, p. 711-718, 2014.

SUDANO, M. J.; SANTOS, V. G.; TATA, A.; FERREIRA, C. R.; PASCHOAL, D. M.; MACHADO, R.; BURATINI, J.; EBERLIN, M. N.; LANDIM-ALVARENGA F. D. C. Phosphatidylcholine and sphingomyelin profiles vary in Bos taurus indicus and Bos taurus taurus in vitro- and in vivo-produced blastocysts. Biology of Reproduction, Madison, v. 87, n. 6, p. 1-11, 2012.

TANIGUCHI, M.; IKEDA, A.; ARIKAWA, E.; WONGSRIKEAO, P.; AGUNG, B.; NAOI, H.; NAGAI, T.; OTOI T. Effect of cryoprotectant composition on in vitro viability of in vitro fertilized and cloned bovine embryos following vitrification and in-straw dilution. Journal of Reproduction and Development, Tokyo, v. 53, n. 4, p. 963-969, 2007.

TSUBOYAMA-KASAOKA, N.; TAKAHASHI, M.; TANEMURA, K.; KIM, H.; TANGE, T.; OKUYAMA, H.; KASAI, M.; IKEMOTO, S.; EZAKI, O. Conjugated linoleic acid supplementation reduces adipose tissue by apoptosis and develops lipodystrophy in mice. Diabetes, Alexandria, v. 49, n. 9, p. 1534-1542, 2000.

WERLICH, D. E.; BARRETA, M. H.; MARTINS, L. T.; VIEIRA, A. D.; MORAES, A. N.; MEZZALIRA, A. Embriões bovinos PIV vitrificados em diferentes soluções crioprotetoras com ou sem o uso de nitrogênio super-resfriado. Acta Scientiae Veterinariae, Porto Alegre, v. 34, n. 1, p. 77-82, 2006.

WOLFE, J.; BRYANT, G. Freezing, drying, and/ or vitrification of membrane-solute-water systems. Cryobiology, Luton, v. 39, n. 2, p. 103-129, 1999. 
